\title{
Wastewater Reuse in Agriculture: A Review about Its Limitations and Benefits
}

\author{
María Fernanda Jaramillo (iD) and Inés Restrepo * \\ Instituto CINARA, Facultad de Ingeniería, Universidad del Valle, Cali 760032, Colombia; \\ maria.f.jaramillo@correounivalle.edu.co \\ * Correspondence: ines.restrepo@correounivalle.edu.co; Tel.: +57-2-339-2345
}

Received: 20 June 2017; Accepted: 19 September 2017; Published: 11 October 2017

\begin{abstract}
For centuries, wastewater has been improperly used in agriculture, presenting potential risks to public health and the environment. In the context of scientific development, and confronted by an increasing water crisis, wastewater reuse merits consideration because the practice helps decrease water use pressure and moderates water pollution. Thus, this article presents a literature review that addresses the effects, both positive and negative, of wastewater use in agriculture, emphasizing the effects on the soil environment. The literature review reveals that, until the 1990s, research studies promoted the use of wastewater for irrigation purposes from a treatment approach, while proposing "end of pipe" conventional solutions. However, more recent research studies (2012-2016) reveal that agricultural reuse significantly affects soil texture properties, while also causing possible alterations of the biomass and microbiota. In addition, research in this period has been oriented to the quantitative evaluation of microbiological risk.
\end{abstract}

Keywords: water pollution control; agricultural reuse; wastewater reuse; agricultural irrigation; efficient use of water

\section{Introduction}

Wastewater reuse in agriculture involves the further use of "treated" wastewater for crop irrigation [1]. This type of reuse is considered an efficient tool for managing water resources [2], stemming from the need for a regulated supply that compensates for water shortages caused by seasonality or the irregular availability of other water sources for crop irrigation throughout the hydrological year [3]. Although the use of wastewater is an ancient practice, it has not always been properly managed or met quality standards according to use. Accordingly, the knowledge pertaining to wastewater use has evolved with the history of mankind [4].

During the Bronze Age (3200-1100 BC), prehistoric civilizations used domestic wastewater in agriculture to dispose of waste from urban settlements. Soil irrigation with wastewater was the most common practice and has since undergone different development stages [5]. The first evidence of wastewater reuse is found among the ancient Greeks, who used public latrines that flushed wastewater through a sewer system towards a storage chamber. Additionally, Greek and Roman civilizations used domestic wastewater at the perimeters of major cities (Athens and Rome) [6]. Wastewater was transported to the agricultural fields to be used as fertilizer for crops and orchards [7].

Between the years 1550 and 1700, the direct use of wastewater on agricultural fields was extended to farms in Germany, Scotland and England [8,9]. Beginning in 1800, soil irrigation with wastewater was adopted in many fast-growing cities in Europe and the United States. For example, the practice was considered legal in cities such as London, Paris and Boston and was considered a solution for the treatment and disposal of large volumes of wastewater $[6,10]$. Paris was the first large city to irrigate peri-urban fields with wastewater. In 1872, the practice in Paris reached its maximum extent, in which four different peri-urban areas were irrigated with wastewater (Gennevilliers, 900 ha; Achères, 1400 ha; 
Pierrelaye, 2010 ha; and Triel, 950 ha). It was during this same period that the disposal of municipal wastewater was also implemented in Australia. In 1897, the first field to be irrigated with wastewater was established in Melbourne [9].

In the 19th century, the transportation and final disposal of untreated wastewater onto open peri-urban fields triggered catastrophic epidemics of waterborne diseases such as cholera and typhoid fever [10]. Such epidemics prompted several milestones in sanitation, such as Great Britain's Public Health Act, establishing the "discharge of rainwater in the river and of wastewater on the soil" as the primary principle [11]. Additionally, the international sanitary movement promoted by leading European powers led to a series of sanitary conferences on hygiene and demography. Furthermore, the International Office of Public Hygiene was established, with the purpose of performing sanitary controls along borders [12]. The development of underground sewage systems that emerged in the mid-19th century is believed to be another response to the unhygienic conditions resulting from the heavy industrialization and urbanization occurring at that time [4]. However, wastewater disposal schemes in agricultural fields continued to be widely adopted by major European cities and the United States until the early 20th century [8,13]. During the 1990s, interest in the use of wastewater for agricultural purposes (indirect irrigation with raw wastewater) increased in many parts of the world due to this sector's high water demands $[1,14,15]$.

During this time, wastewater reuse was a global concern due to the associated risks to public health and the environment. Thus, in 1973, the World Health Organization (WHO) drafted the document "Reuse of effluents: methods of wastewater treatment and health safeguards", with the aim of protecting public health and facilitating the rational use of wastewater and excreta in agriculture and aquaculture. This initial guideline was drafted in the absence of epidemiological studies and from a minimal risk approach [16]. In 1986, a thorough analysis of all available epidemiological studies was performed, compiling a series of evidence that reflected a need to review the guidelines established in 1973. Based on these considerations, the guidelines were later updated in 1989 and new health evidence was incorporated, such as risk assessments, along with additional information on the definition of tolerable risks for society based on the present situation of a particular disease in a country [16]. In the guidelines, parameters were established on the microbiological quality of wastewater for irrigation. However, the WHO guidelines [17] did not include surveillance guidelines; therefore, their formulation was proposed on the basis of objectives and health protection measures $[18,19]$. Such considerations were incorporated as part of the wastewater guidelines produced by the WHO in 2006.

The WHO's 2006 guidelines for the safe use of wastewater, excreta and graywater constitute a tool for the preventive management of wastewater in agriculture and provide clear guidance for decision-makers on wastewater application in different local contexts. The guidelines' primary purpose is to support the formulation of standards and government regulations regarding the use and management of wastewater, considering the specific aspects of every country [19-21]. Such guidelines consisted of an essential microbiological analysis for risk assessment that includes data collection on pathogens present in wastewater, fields and irrigated crops. In addition, the guidelines include estimations on health risk management and prevention for wastewater use, based on the disability-adjusted life year and person per year (DALY and PPY, respectively).

The Food and Agriculture Organization of the United Nations (FAO) has also developed several guidelines relevant to the use of wastewater in agriculture. In 1987, the wastewater quality guidelines for agricultural use were published. These guidelines related the degree of restriction of water use to salinity, infiltration and toxicity parameters of specific ions [22]. In 1999, the FAO published the suggested guidelines for the "agricultural reuse of treated waters and treatment requirements". In these guidelines, the type of agricultural reuse was classified on the basis of the type of irrigated crop [23] (Table 1). 
Table 1. FAO guidelines for the agricultural reuse of treated water.

\begin{tabular}{ccc}
\hline Type of Agricultural Reuse & Type of Treatment & Quality Criterion \\
\hline $\begin{array}{c}\text { Agricultural reuse in crops that are } \\
\text { consumed and not processed } \\
\text { commercially. }\end{array}$ & $\begin{array}{c}\text { Secondary } \\
\mathrm{pH}=6.5-8.4 \\
\mathrm{BOD}<10 \mathrm{mg} / \mathrm{L} \\
<2 \mathrm{UNT}\end{array}$ \\
$\begin{array}{c}\text { Agricultural reuse in crops that are } \\
\text { consumed and not processed } \\
\text { commercially. }\end{array}$ & Secondary-Disinfection & $<14 \mathrm{NMP}$. coli $/ 100 \mathrm{~mL}$ \\
& & $\mathrm{pH}=6.5-8.4$ \\
& & $\mathrm{BOD}<30 \mathrm{mg} / \mathrm{L}$ \\
$\mathrm{SS}<30 \mathrm{mg} / \mathrm{L}$ \\
$\begin{array}{c}\text { Agricultural reuse in crops that are } \\
\text { not consumed. }\end{array}$ & Secondary-Disinfection & $<200 \mathrm{NMP}$ E. coli/100 mL \\
\hline
\end{tabular}

In 1992, the Environmental Protection Agency (EPA) confirmed the toxic effects on crops exposed to certain trace elements present in wastewater used for irrigation. In 2004, the EPA expanded the scope of indirect potable reuse and industrial reuse issues to include many new and updated case studies, new information on treatment and disinfection technologies, emerging chemicals and pathogens of concern, economics, user rates and funding alternatives, public involvement and acceptance, research activities and sources of information [24].

In 2012, the EPA and the United States Agency for International Development (USAID) updated the Guidelines for Wastewater Reuse. The main objective of the update was to facilitate the development of wastewater reuse based on a compilation of global experiences. The 2012 guidelines included an updated analysis of the regional variations of water reuse, advances in wastewater treatment technologies, best practices to involve communities in planning projects, international water reuse practices and factors that support the expansion of safe and sustainable water reuse. More than 300 experts in the wastewater reuse field collaborated in providing technical updates of the guidelines, technical revisions, information on standards and case studies. On the basis of quality, the EPA and USAID [25] recommended there be a maximum safe concentration level of trace elements present in irrigation water. The guidelines of the WHO, FAO and EPA have been the basis for the formulation of the regulations in different countries in the world.

Between the years 2000 and 2006, more than 3300 wastewater facilities were registered worldwide, within the framework of the AQUAREC international project. The various wastewater facilities were characterized by different water treatment quality levels and use types, agriculture being the primary wastewater user [26]. The countries with the greatest number of reuse facilities were Japan and the United States (1800 and 800, respectively), followed by Australia and the European Union with 450 and 230, respectively. In the Mediterranean and Middle East regions, approximately 100 wastewater treatment facilities were identified, whereas Latin America was reported to have 50 facilities, and Sub-Saharan Africa had 20 [26].

The FAO reported that approximately $10 \%$ of the total global irrigated land area receives untreated or partially treated wastewater, encompassing 20 million hectares in 50 countries [27]. However, Jiménez and Asano [15] reported that the estimated wastewater-irrigated area discriminates by country and by treated and untreated conditions (Figure 1). Regarding the volume of wastewater used in agriculture, Bixio and Wintgens [28] reported that the European continent reuses $963 \mathrm{Mm}^{3} /$ year of untreated wastewater. In Latin America, approximately $400 \mathrm{~m}^{3} / \mathrm{s}$ of raw wastewater is discharged and subsequently used to irrigate different crops [29]. 


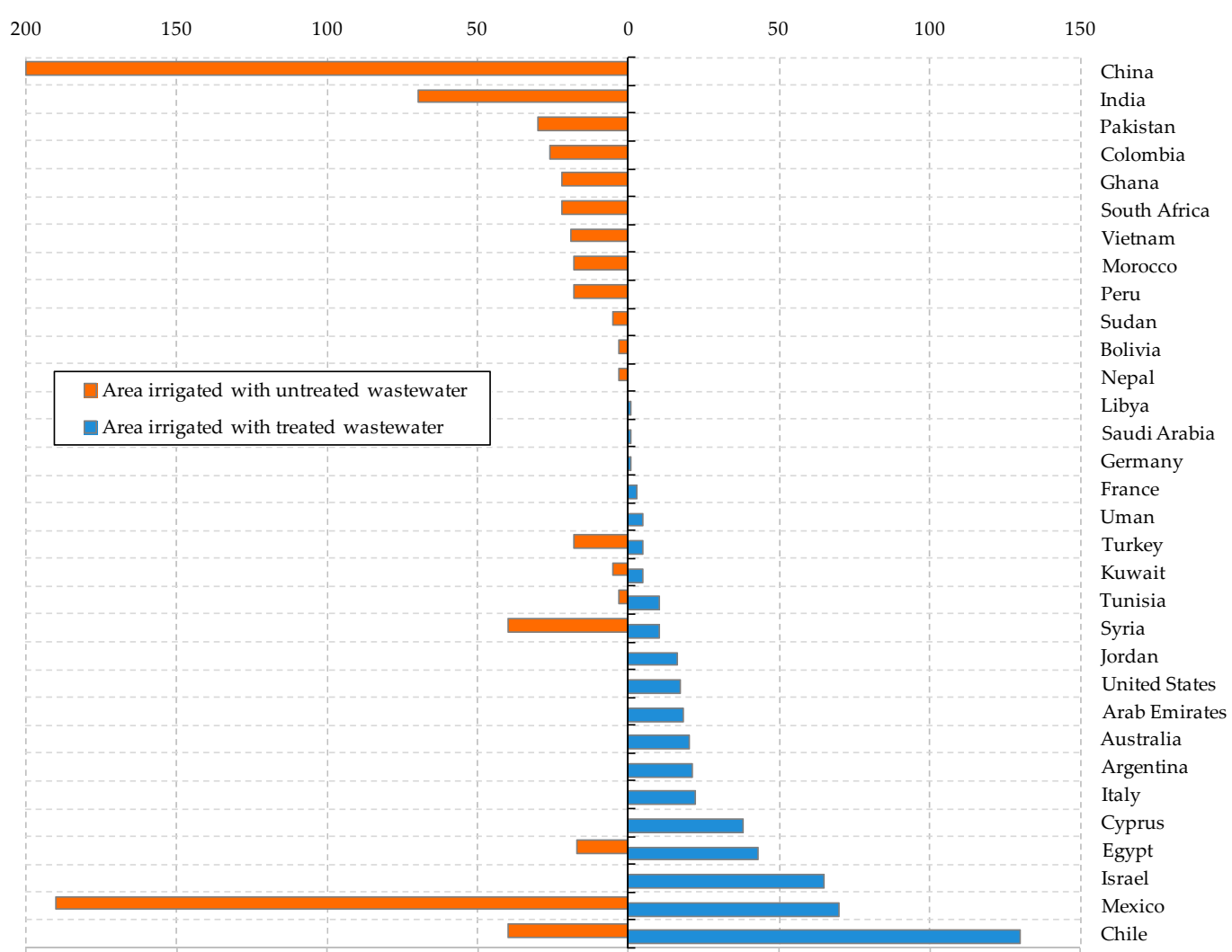

Figure 1. Reuse area in agriculture by country (thousand ha); Source: Jiménez and Asano [15].

This article reviews the effects, both positive and negative, of wastewater reuse in agriculture. This practice is important, especially in the context of developing countries confronted with increased water shortages due to variability and climate change.

\section{Benefits of Agricultural Reuse}

The use of treated wastewater in agriculture benefits human health, the environment and the economy. This use represents an alternative practice that is being adopted in different regions confronted with water shortages and growing urban populations with increasing water needs [27,30,31], especially given the decline in surface and groundwater resources caused by climate variability $(\mathrm{CV})$ and climate change (CC). The availability of water resources is also affected by wastewater-sourced pollution, as such water is not always treated before reaching surface channels, and by associated aquifer pollution $[27,31,32]$.

One of the most recognized benefits of wastewater use in agriculture is the associated decrease in pressure on freshwater sources. Thus, wastewater serves as an alternative irrigation source [27], especially for agriculture, the greatest global water user, which consumes $70 \%$ of available water [33]. Furthermore, wastewater reuse increases agricultural production in regions experiencing water shortages, thus contributing to food safety [34]. Approximately 805 million people, one-ninth of the global population, suffer from hunger. However, according to FAO's latest estimations, a decreasing trend in hunger supports the possibility of halving the number of undernourished people. However, to be successful, it is first necessary to adopt a comprehensive approach that includes public and private investment aimed at increasing agricultural productivity, in addition to increasing and improving the availability of water resources and protecting vulnerable groups [35].

Depending on the local situation, another benefit associated with agricultural wastewater reuse could be the avoided cost of extracting groundwater resources. In this regard, it is worth noting that the energy required to pump groundwater can represent up to $65 \%$ of the costs of irrigation activities [36]. 
Additionally, the nutrients naturally present in wastewater allow savings on fertilizer expenses to be realized $[8,27,34,37]$, thus ensuring a closed and environmentally favorable nutrient cycle that avoids the indirect return of macro- (especially nitrogen and phosphorous) and microelements to water bodies. Depending on the nutrients, wastewater may be a potential source of macro- (N, P and K) and micronutrients ( $\mathrm{Ca}, \mathrm{Mg}, \mathrm{B}, \mathrm{Mg}, \mathrm{Fe}, \mathrm{Mn}$ or $\mathrm{Zn}$ ) [38-40]. Indeed, wastewater reuse has been proven to improve crop yield [37,41-44] and result in the reduced use of fertilizers in agriculture [45-48]. Therefore, eutrophication conditions in water bodies would be reduced, as would the expenses for agrochemicals used by farmers $[3,49]$.

The prevention of water pollution would be another benefit associated with wastewater reuse in agriculture. A decrease in wastewater discharge helps improve the source quality of receiving water bodies [28,47]. Moreover, groundwater reservoirs are preserved, as agricultural wastewater reuse recharges these sources with higher-quality water [50]. Additionally, an increased use of wastewater could contribute to the installation and optimization of treatment facilities to produce effluent of a desired quality for irrigation purposes, representing an economic benefit to sanitation projects [51]. In those areas where climatic and geographic characteristics allow, low-cost wastewater treatment systems might also be a viable option, achieved using certain technological options that fulfill the objective of agricultural reuse [27].

Wastewater use in agriculture helps liberate capital resources through the payment of economic instruments by the actors of different countries [3]. An implicit economic benefit of agricultural wastewater reuse is the valuation of the treated water discharged for human consumption, as this use is considered to be of highest priority. In some countries, wastewater reuse contributes to reducing the municipal cost of searching for water sources using more expensive means [27]. On the basis of regulatory aspects, agricultural wastewater reuse can contribute to the justification of suitable investment policies and financing mechanisms for pollution control and prevention [52].

\section{Health Risks of Agricultural Wastewater Reuse}

The concentration levels and types of pathogens and chemical substances present in wastewater vary by region, according to the sanitary and socioeconomic conditions of a particular community [53]. The concentration of viruses, protozoan parasites and helminths in wastewater can be 10-1000 times higher in developing countries than in developed countries [54]. Table 2 presents the primary types of enteric pathogens and substances of sanitary interest that can be found in wastewater used for agricultural irrigation.

Table 2. Chemical and biological risks associated with the use of raw wastewater in agriculture.

\begin{tabular}{|c|c|c|}
\hline Type of Risk & & Pathogen \\
\hline \multirow{5}{*}{ Biological } & Bacteria ${ }^{1}$ & E. coli, Vibrio cholerae, Salmonella spp., Shigella spp. \\
\hline & Helminths ${ }^{1}$ & Ascaris, Ancylostoma, Tenia spp. \\
\hline & Protozoans ${ }^{1}$ & Intestinal Giardia, Crysptospridium, Entamoeba spp. \\
\hline & Virus $^{1}$ & Hepatitis A and E, Adenovirus, Rotavirus, Norovirus \\
\hline & Schistosoma $^{2}$ & Blood-flukes \\
\hline \multirow{4}{*}{ Chemical } & Substance of sanitary interest & \\
\hline & Heavy Metals 2 & Arsenic, Cadmium, Mercury \\
\hline & Hydrocarbons $^{2}$ & Dioxins, Furans, PCBs \\
\hline & Pesticides ${ }^{1}$ & Aldrin, DDT \\
\hline
\end{tabular}

${ }^{1}$ Contact and/or consumption; ${ }^{2}$ Consumption; Source: WHO [21].

Wastewater-borne diseases can also be chronic or acute [55]. Acute risk corresponds to the possibility of becoming ill in the short-term when exposed to low infectious doses of a pollutant, whereas chronic risk refers to the presence of pollutants of a chemical nature that affect human health after long periods of exposure [56]. Additionally, microbial diseases can be directly or indirectly 
transmitted by water (Table 3). Globally, such diseases have significantly contributed to premature mortality, especially in developing countries [55].

Table 3. Some water-borne diseases related to wastewater.

\begin{tabular}{|c|c|}
\hline Disease & Cause \\
\hline Typhoid fever & Salmonella typhi \\
\hline Paratyphoid fever ${ }^{2}$ & Salmonella paratyphi \\
\hline Gastroenteritis ${ }^{1}$ & Salmonella typhimurium \\
\hline Cholera $^{2}$ & Vibrio cholerae \\
\hline Bacillary dysentery ${ }^{2}$ & Shigella dysenteriae \\
\hline Amebiasis ${ }^{2}$ & Entamoeba histolytica \\
\hline Giardiasis $^{1}$ & Giardia duodenalis \\
\hline Cryptosporidiosis ${ }^{1}$ & Cryptosporidium \\
\hline Cyclosporiasis 2 & Cyclospora cayetanensis \\
\hline Infectious hepatitis ${ }^{1}$ & Hepatitis A \\
\hline Gastroenteritis ${ }^{2}$ & Enterovirus, parvovirus, rotavirus \\
\hline Infantile paralysis & Poliovirus \\
\hline Leptospirosis ${ }^{1}$ & Leptospira icterohaemorrhagiae \\
\hline Ear infections & Pseudomonas aeruginosa \\
\hline Scabies & Sarcoptes scabiei \\
\hline Trachoma & Chlamydia trachomatis \\
\hline Schistosomiasis ${ }^{2}$ & Schistosoma \\
\hline Malaria & Plasmodium \\
\hline Yellow fever & Flavivirus \\
\hline Dengue & Flavivirus \\
\hline
\end{tabular}

${ }^{1}$ Human and/or animal excrement, ${ }^{2}$ Human excrement; Sources: Romero [57], Von Sperling [58], Jiménez and Rose [59], Evans and Mara [60].

Other compounds present in irrigated wastewater that may pose risks to human health are emerging contaminants (ECs). ECs are molecules with biological activity on different organisms, and their physicochemical properties determine their persistence in the environment and facilitate their bioaccumulation. ECs include analgesics, antihypertensive drugs and antibiotics, among others. Furthermore, some ECs correspond to endocrine disrupters (EDs) [51]. Such substances, of complex nature, were not considered contaminants in the past, because of a lack of information on their accumulation in soil, water, air and vegetal and animal tissue. However, since the 1990s, the concentration of these compounds began to be quantified in water sources [61]. Countries such as Spain, Italy, Germany, Canada, Brazil, Greece and France have estimated that loads of analgesics weighing approximately 500 tons have been discharged into superficial water sources, in which salicylic acid and diclofenac have reached concentrations of $0.22 \mu \mathrm{g} / \mathrm{L}$ and $3.02 \mu \mathrm{g} / \mathrm{L}$, respectively [62]. ECs are regularly introduced into aquatic media through different anthropogenic sources, which can consequently result in toxic residues and adverse effects on aquatic organisms and, ultimately, on humans [63]. The effluents of municipal wastewater treatment plants are classified as one of the primary EC sources, as conventional treatment processes do not effectively prevent the release of these compounds into the environment [64]. Additionally, agriculture and farming, as sources of diffuse pollution from pesticides and antibiotics, respectively, are classified as additional EC sources [65].

Other sources of superficial water contamination by ECs may occur as a result of runoff from soils that contain animal excreta or sludge digested from wastewater treatment systems used as fertilizers or fertirrigation. Groundwater contamination by ECs may occur as a result of landfill leachate, the leakage of manure containers or from spray irrigation with treated or untreated wastewater on agricultural land [66].

The effects on human health caused by ECs are not yet fully understood [67]. However, many of these compounds are known to alter the endocrine and immunological systems of aquatic organisms [68]. In general, all compounds that affect the endocrine system are defined as endocrine disrupters (EDs). 
These EDs have been shown to produce hormonal changes in some fish species and amphibians [69]; some changes are associated with the secretion of stimulating hormones of the thyroid gland (TSH), the luteinizing hormone (LH) and the follicle stimulating hormone (FSH). Other drugs such as clofibrate, carbamazepine and fluoxetine also modify endocrine activity. Moreover, ED drugs cannot be easily removed in wastewater treatment facilities. Consequently, EDs enter superficial waters and water sources intended for human consumption, thus chronically exposing human beings to their toxic effects [70].

Contamination by ECs can contribute to the formation of resistant microorganisms. The extended use of antibiotics against pathogenic microorganisms in animals and humans, as well as their use for food preservation, has increased their production and consumption, thus resulting in high-volume discharge rates into water bodies with consequences of microbial resistance [61]. Among those microorganisms that have demonstrated resistance, some are especially notable: Staphylococcus, Aeromonas, Pseudomonas, Salmonella and Escherichia [71]. Thus, in the context of legal policies and functionality, the presence of resistant microorganisms in water bodies is an issue of great concern as it relates to public health and wastewater treatment and reuse systems [61].

\section{Limitations Associated with Agricultural Wastewater Reuse}

The use of treated or untreated wastewater in agriculture is not exempt from adverse effects on the environment, especially on soil. The scientific literature includes evidence of alterations in the physicochemical parameters of soil [30]. Additionally, in recent research, variations have been observed in the structure and magnitude of microbial biomass in soil, as well as an increase in microbial activity caused by agricultural wastewater reuse [30]. Altering physicochemical parameters and soil microbiota can affect fertility and productivity, thus disturbing soil sustainability from inadequate irrigation with wastewater [30]. A review follows on the effects of wastewater reuse in agriculture and the impact on physicochemical parameters such as $\mathrm{pH}$, organic matter, nutrients, salinity and contaminants, as well as on microbial diversity. Table 4 presents different research studies that have been conducted on the effects of wastewater on soil.

Several research studies have reported variations in soil $\mathrm{pH}$ resulting from irrigation with effluents from municipal wastewater treatment systems at different treatment levels (preliminary, primary and secondary). Additionally, changes in soil $\mathrm{pH}$ are correlated with three factors: (i) type of soil cover; (ii) soil texture; and (iii) period of irrigation [30]. The changes in soil $\mathrm{pH}$ influence the availability of nutrients and metals $[72,73]$, the cation exchange capacity (CEC) and the mineralization of organic matter [74].

Additionally, different researchers consider $\mathrm{pH}$ incidence to be a decisive factor in determining the number of species and variety of soil microorganisms, as an increase in free metals is not related to changes in the soil $\mathrm{pH}$, and the concentration and availability of metals have the potential to affect the substrate of the microbial communities [75-78].

Moreover, organic matter is critical for nutrient storage and soil structure. Through the formation and stabilization of aggregates (sand, lime and clay), the organic matter content contributes to the capacity of the soil to retain water, affecting drainage properties and compaction resistance [79]. Organic matter also constitutes a deposit of important macro- and micronutrients (N, P and S) for plant growth [79-81], contributing to the cation exchange capacity (CEC) and, consequently, to soil fertility [82-84]. Depending on the amount of organic matter contributed, different studies (see Table 4) have reported an increase in total organic carbon (TOC) and nitrogen (N) in those soils irrigated with domestic wastewater. This phenomenon also causes the availability of organic matter to increase. As a consequence, the presence of specific bacteria populations may be favored in the soil [85]. Between $40 \%$ and $70 \%$ of soil bacteria are associated with stable aggregates (clay particles) [86]. 
Table 4. The influence of agricultural reuse on the soil's physicochemical and microbiological parameters.

\begin{tabular}{|c|c|c|c|}
\hline \multirow{2}{*}{ Parameter } & \multicolumn{2}{|c|}{ Associated Effects on the Soil and the Environment } & \multirow{2}{*}{ References } \\
\hline & Physicochemical Properties & $\begin{array}{c}\text { Microbiological } \\
\text { Properties }\end{array}$ & \\
\hline $\mathrm{pH}$ & $\begin{array}{l}\text { Increases the availability of nutrients and metals } \\
\text { Mineralization of organic matter } \\
\text { Improves the cation exchange capacity }\end{array}$ & $\begin{array}{l}\text { Increases the richness } \\
\text { and diversity of the } \\
\text { microbial community }\end{array}$ & {$[72,73,75-78,87]$} \\
\hline Organic matter & $\begin{array}{c}\text { Soil structure stabilization } \\
\text { Formation of aggregates } \\
\text { Water retention } \\
\text { Improves nutrient content } \\
\text { Buffer Capacity } \\
\text { Cation exchange capacity } \\
\text { Enzymatic activity } \\
\text { Increase in TOC } \\
\text { Increases the availability of contaminants }\end{array}$ & $\begin{array}{l}\text { Selection of specific } \\
\text { populations and soil } \\
\text { microhabitats }\end{array}$ & {$[73,75,76,78-81,83,84,86-90]$} \\
\hline Nutrients & $\begin{array}{c}\text { Increase in organic soil matter } \\
\text { Water retention } \\
\text { Leaching to groundwater } \\
\text { Improves nutrient content } \\
\text { Risk of eutrophication of aquatic environments }\end{array}$ & $\begin{array}{l}\text { Perturbation of the } \\
\text { metabolic activity of } \\
\text { microbial soil } \\
\text { communities }\end{array}$ & {$[37,39-43,49,91-100]$} \\
\hline Salinity & $\begin{array}{c}\text { Soil salinization or sodification } \\
\text { Decreased stability of aggregates } \\
\text { Changes in soil structure in the long term } \\
\text { Permeability of soil and water retention } \\
\text { Increased soil compaction } \\
\text { Variation in soil pH } \\
\text { Negative impact on soil fertility } \\
\text { Dynamics in organic and inorganic compounds } \\
\text { Heavy metal leaching }\end{array}$ & $\begin{array}{l}\text { Changes in soil } \\
\text { microhabitats and } \\
\text { variation in the richness } \\
\text { and diversity of the } \\
\text { microbial community }\end{array}$ & {$[22,76,101-113]$} \\
\hline Contaminants & $\begin{array}{c}\text { Soil toxicity and leaching } \\
\text { Accumulation in soils } \\
\text { Negative impact on soil fertility } \\
\text { Potential contamination of the food chain } \\
\text { Mineralization of organic matter } \\
\text { Changes in enzyme activity } \\
\text { Decomposition of fallen leaves } \\
\text { Limiting soil fertility }\end{array}$ & $\begin{array}{l}\text { Increased tolerance to } \\
\text { microbial contaminants. } \\
\text { Antimicrobial resistance. } \\
\text { Reduction of microbial } \\
\text { biomass and changes in } \\
\text { its structure }\end{array}$ & {$[30,82,91,92,95,96,99,114-135]$} \\
\hline
\end{tabular}

The stability of aggregates in the soil and the water retention capacity from the organic matter contributed by wastewater irrigation depend on the concentration levels, the composition of organic matter and soil texture. Thus, sandy-clay soils irrigated with wastewater increase the stability of their aggregates [88]. Conversely, soils with a clayey texture diminish the stability of their aggregates [88]. Additionally, the use of wastewater in prolonged irrigation (more than 20 years) can result in negative changes in soil structure due to the accumulation of sodium in the exchange complex [89]. A study on sugarcane irrigated with treated wastewater for 12 months found an increase in the content of organic matter in the soil that, according to the authors, favored the reuse of wastewater in the areas under study (Valle del Cauca, Cali, Colombia) [90].

Different research studies (Table 4) have noted an increase in the different forms of nitrogen $\left(\mathrm{N}-\mathrm{NO}_{3}, \mathrm{NH}_{4}-\mathrm{N}\right.$ or Total $\left.\mathrm{N}\right)$ after irrigation with wastewater for periods ranging from one to 20 years. However, despite existing benefits in agricultural production and a reduction in chemical agents (fertilizers) from the increase in $\mathrm{N}$ and $\mathrm{P}$ contributed by wastewater, soil microbial communities can be affected, particularly the activities associated with the cycle of these elements

More than ninety percent of the soil's nitrogen is in organic form. Ammonium and nitrate are the main forms of absorption by plants, in addition to some organic nitrogen compounds [136]. It is generally believed that nitrite is an intermediate product in the conversion of Ammonium to Nitrate in the soil, where the conversion of Nitrite to Nitrate is important, since relatively small amounts may have toxic effects on plant growth [137]. These intermediate products of complex organic substances of nitrogen can be absorbed by the plants. Organic nitrogen nutrition can affect the quality of the 
plant product and the metabolism of the plan [136]. Similarly, under excessive application of nitrogen (by fertilizer, sewage, or other source), vegetables can accumulate high levels of nitrate and, when consumed by living things, can pose serious health hazards [138].

Another effect is he accumulation of inorganic $\mathrm{N}$ in the soil that can affect the biodegradation of carbon compounds [91,96]. Additionally, the excessive supply of nutrients in the soil may have adverse effects. Nutrients such as phosphorus and nitrate can be included in the runoff or can be leached towards groundwater, thus causing the eutrophication or toxicity of other habitats $[49,139]$.

Irrigated wastewater can promote soil salinization (an increase in the concentration of soluble salts) or sodification (an excess of interchangeable sodium in relation to other cations) [107]. Salinity problems occur when the soluble salts are concentrated in the root zone [106], thus causing osmotic stress that limits the capacity of plants to absorb water and nutrients [105].

Sodicity therefore negatively affects the stability of aggregates and soil structure, as high interchangeable sodium content causes a decrease in permeability [73]. Sodicity is caused by expansive and dispersive processes on clays as a consequence of the destruction of aggregates due to high $\mathrm{Na}^{+}$ concentrations $[109,110]$. Different research studies noted that changes in sodicity generate an increase in soil compaction and reduce the infiltration rate of water $[108,109,111]$.

As a result, soil microbiota is affected by variations in soil salinity or sodicity. The effects on microbial communities are primarily related to changes in soil structure and decreases in osmotic potential [102,103,112].

Another study assessed the effects of salinity on the structure, activity and community of soil microorganisms. Their results suggest that higher salinity content metabolically stresses soil microbiota [113]. Additionally, the Carbon Nitrogen relation of the biomass tends to be lower in higher salinity soils, which reflects the predominance of bacteria in the microbial biomass of saline soils.

Furthermore, soil degradation increases due to the disposal of pollutants (metals and pharmaceutical compounds) through different media such as wastewater, which accumulate in the soil as a result of irrigation [30]. Typically, metal concentrations in soils not subjected to anthropogenic activities depend primarily on the parental material (stone) and can be present in the soil at non-toxic levels for living beings. However, population growth and industrialization have resulted in an increase in the presence of such polluting agents in wastewater and, consequently, in irrigated soils [126]. Metals such as $\mathrm{Fe}, \mathrm{Cr}$, $\mathrm{Zn}, \mathrm{Pb}, \mathrm{Ni}, \mathrm{Cd}$ and $\mathrm{Cu}$, which are abundant in wastewater, lead the list of possible polluting agents that have accumulated in soil as a result of wastewater irrigation. The presence of these elements in the soil can limit fertility and/or modify soil microbial communities [30]; they also affect a soil's phytotoxicity potential with consequent effects on plant growth and pollution. Other ecosystem functions affected due to metal pollution include organic matter mineralization, changes in soil enzyme activity, litter decomposition, microbial biomass reduction and changes in microbial structure $[118,124,125,130]$.

Additionally, the metals accumulated in a soil can interact with pharmaceutical products or other ECs, exacerbating the potential effects on the soil. Several studies have also noted strong co-occurrence patterns between the metals in a soil and a resistance to antibiotics in certain environmental conditions $[123,127,129,140]$. The fate and effect of these compounds (emerging metals and/or polluting agents) depend on several factors such as the chemical properties of the pollutant type, the species and age of the vegetation cover, the composition of the rhizosphere microorganisms and soil characteristics (temperature, $\mathrm{pH}$ of the nutritional environment, soil texture and structure) [128]. Some researchers have noted that low-mobility compounds accumulate in soils with an irrigation period ranging from one to 100 years, in contrast with high-mobility compounds [141-144].

Additionally, researchers worldwide have highlighted the risks posed by high-mobility compounds, given the possible leaching that may pollute groundwater sources $[131,132,134,135]$. For example, in some amoxicillin-degradation products, it was observed that high-mobility compounds polluted the groundwater of wastewater-irrigated agricultural fields [133]. Another study concluded, after discovering low retention rates for ibuprofen in soils, that this compound has a high potential to percolate through soil and pollute groundwater sources [145]. 


\section{Assessment of the Risk Associated with the Use of Wastewater in Agriculture}

The use of wastewater in agriculture has limitations due to the risks associated with the different routes of exposure, exposed groups and concentrations of various physicochemical and microbiological parameters. Thus, soil as a means of receiving wastewater, the irrigation method, the type of irrigated crop, the products consumed, farmers and their families and final consumers, are exposed throughout the process chain [146]. With the development of the WHO guidelines of 1989, it was recognized that human parasites are the main risk to human health and the development of wastewater treatment systems for risk reduction was proposed as the main strategy. Thus, the concept of "zero risk" could only be achieved under technological schemes of primary, secondary and disinfection treatment, technically feasible but not a feasible solution in the practical and economic context of developing countries [147].

With the development of the WHO guidelines of 2006, the need to know the magnitude of the risk associated with this type of practice was clearly formulated and the conceptual bases for its estimation were formulated, recognizing with this that strategies for risk reduction should be flexible and adjusted to the local context and for the first time suppressed the effluent quality thresholds [147]. Thus, the concept of "multiple barriers" was introduced. It proposed a series of barriers along the reuse chain, instead of focusing only on treatment infrastructure for the improvement of wastewater quality to be reused [148]. The WHO guidelines (2006) [21] raised the health-based goals, which are estimated from a standard measure of disease selected in relation to the Disability Adjusted Life Year (DALY). DALY is a quantitative indicator of disease burden, which represents the total amount of healthy life reduced because of a disability, or the lifetime that is lost due to premature mortality. The objective formulated corresponded to $\leq 10^{-6}$ DALY per person, which is the estimated disease burden associated with mild diarrhea [149].

According to the literature, the risk assessment can be performed using three types of studies: (i) microbiological laboratory tests; (ii) epidemiological studies; and (iii) quantitative microbiological risk assessment (QMRA). Microbiological studies are considered as a source of information for types of studies (ii) and (iii) and are only appropriate if health assessments and appropriate protective measures are taken to avoid a health risk [147]. Epidemiological studies are a direct measure of the associated risk, but their complexity and target population requirements and high costs may limit the technique [21]. The QMRA is considered an indirect risk measurement that has been widely used, but its results are associated with the specific scenarios evaluated [147]. The combined use of the three types of studies for risk estimation may yield better results in their evaluation, notwithstanding the costs associated with each type of study, the population size and time required, the required input information, and the difficulty of modeling, are some of the limitations that determine the prioritization of the use or the combined use of these tools [21].

Quantitative microbiological risk assessment (QMRA) has been considered an essential component of risk management [150]. A probabilistic modeling technique to estimate the magnitude of risk under specific scenarios $[151,152]$ and its implementation is defined in four steps: (i) hazard identification; (ii) exposure assessment; (iii) dose-response modeling; and (iv) risk characterization. The use of this technique in relation to the wastewater reuse in agriculture has been focused on the risk assessment in raw consumer products, especially on varieties of lettuce and some vegetables, and rotavirus infection as a major cause of diarrheal disease in the world [153].

In 1992, a review of the data accumulated in the period from 1975 to 1989 led to the reformulation of the quality criteria of wastewater of the state of California (United States). Based on the above, a comparative study was carried out of the possible risks of enteric virus infection with secondary and tertiary effluents from treatment systems, as opposed to four exposure scenarios for wastewater use (irrigation of food crops, golf courses, recreational reservoirs and the recharge of aquifers). The analyzes of this study showed that the annual risk of exposing a tertiary effluent with chlorine disinfection, with a viral unit content of $100 \mathrm{~L}$, entails an associated risk in golf courses and recreational reservoirs in a range of $10^{-2}$ to $10^{-7}$, while in crop irrigation and aquifer recharge, it may have an associated 
risk between $10^{-6}$ and $10^{-11}$ [154]. These are determining results for the formulation of mitigation strategies and the prioritization of the investment.

Quantitative microbiological risk assessments associated with virus in lettuce crops have been the most commonly evaluated. Petterson et al. [155] evaluated the impact of two risk factors: (i) the density function associated with the occurrence of human enterovirus in irrigation water; and (ii) the mortality rates for the virus in lettuce cultivation. Under an application of the Monte Carlo simulation method, researchers observed that changes in density function had minimal variations in estimated infection rates. However, the predicted infection rates were more sensitive than the virus decay rates.

Hamilton et al. [150] designed a Decision Support tool called RIRA (Recycled water Irrigation Risk Analysis). This tool helps water and public health managers to conduct Quantitative Microbiological Risk Assessments. RIRA was designed to simulate a wide range of scenarios by defining the pathogen of interest and the exposure scenario, using specific dose-response models. The main advantage of RIRA is its generic and flexible structure, which can be used to carry out risk assessments in accordance with the methods recommended in the main guidelines on recycled water and local context scenarios.

Barker et al. [152] developed a QMRA model to estimate the burden of norovirus disease associated with the consumption of irrigated lettuce with untreated gray water, a practice commonly performed in Australia and not endorsed by normative guidelines. The estimated annual disease burden fluctuated over a range of $2 \times 10^{-8}$ and $5 \times 10^{-4}$ depending on the source of gray water and of how thoroughly the consumer washes the product at home. The model predicted disease loads of $4 \times 10^{-9}$ and $3 \times 10^{-6}$ for bath and washing waters respectively. Using these results, the authors recommended the use of bath water that conforms to normative standards in Australia (threshold value $10^{-6}$ DALY per person). In addition, in Australia, a QMRA model was developed to know the risk of irrigation with wastewater in other types of vegetables such as lettuce, broccoli, cabbage, Asian vegetables and cucumber. Norovirus concentration was used, using faecal dumping rates in black wastewater and the annual norovirus disease burden after irrigation with treated wastewater [151]. The annual estimates of disease burden showed that the primary treatment scenarios evaluated fluctuated within a range of $10^{-5}$ to $10^{-3}$ DALY per person, exceeding all mean values suggested by the WHO and Australian regulations (threshold $\leq 10^{-6}$ DALY per person). However, in the advanced treatment scenarios, most of the cucumber consumption scenarios obtained mean values of disease burden that met the threshold. In general, lettuce consumption posed the greatest risks, while cucumber consumption had the lowest risks. This research was relevant because it was the first QMRA to consider viral accumulation by irrigation using wastewater.

Hamilton and Mok [156] conducted an experiment to determine the volume of water collected in Asian vegetables and lettuce after irrigation by sprinkling with wastewater. The proposed objective contributed to the decrease in the knowledge gap, associated with the estimation of rotavirus microbiological risk in high consumption products in China. Four vegetables were evaluated. The predicted annual probability of infection was $7 \times 10^{-4}$ for the consumption of bok choy, $4 \times 10^{-3}$ for choy and $2 \times 10^{-3}$ for him gai lan and lettuce. Likewise, the annual average disease burden ranged between $5 \times 10^{-6}$ DALY per person and $3 \times 10^{-5}$ DALY per person for the consumption of bok choy and suma choy, respectively. The disease burden for gai lan and lettuce was $2 \times 10^{-5}$ DALY per person. This was the first presentation of water retention measurements for Asian vegetables, as well as the first viral risk assessment for the consumption of vegetables from wastewater in China. This research is significant because China is home to one-fifth of the world's population, and because of the availability of data on rotavirus concentrations, documented as the predominant cause of diarrheal disease in children [153].

Another study was conducted in Ghana to assess the risk associated with water used in the irrigation of vegetables. Pollution parameters evaluated were fecal coliforms and helminth eggs. The water quality was monitored during two months and their concentration levels ranged from 3 to $4 \log$ units of fecal coliforms in $100 \mathrm{~mL}$ and from 6 to 15 eggs of helminth per L. Regarding the evaluated product of consumption (lettuce) the concentration of fecal coliforms ranged from 
$7 \times 10^{2}$ and $1.8 \times 10^{3}$ in $10 \mathrm{~g}$ and the helminth eggs ranged from 6 to 9 per $100 \mathrm{~g}$. The annual risk of infection was $10^{-2}$ for Ascaris and $10^{-1}$ for E. coli. This study is relevant for its development in the risk assessment for possible infections caused by helminths and E. coli [157].

According to Jiménez et al. [158] the lack of scientific knowledge related to the use of wastewater still resides in the evaluation of the microbiological risk associated with the infection caused by helminths. The WHO and EPA guidelines were based on limited epidemiological evidence, rather than the results of a risk assessment. None of these organizations based their recommendations on dose-response curve results, because methodologies had not been sufficiently developed. At the moment, only the risk concerning helminths has been evaluated through laboratory analysis and epidemiological studies. This fact contrasts the development of multiple dose-response models for bacteria, viruses and protozoa. Despite the fact that the WHO recognized that helminths represent a real risk of infection due to its resistance and persistence in the environment and to the minimum infective dose, the development of measurement techniques of this microorganism are in early stages, which depend on direct observation under the microscope with this subjectivity in the results [148]. In addition, in developing countries, regulations do not commonly associate helminths and protozoa, because in these countries, intestinal worm diseases are low among the population.

\section{Conclusions}

Globally, agriculture is a major consumer of wastewater. The search for alternative irrigation sources is believed to be vital to ensure food safety and to preserve natural water bodies. The safe use of wastewater, as an alternative source of irrigation, is an acknowledged strategy for the efficient use and prevention of water pollution that is gaining increasing relevance worldwide, especially in countries confronted with water shortages. However, there are risks associated with this type of use that must be assessed against a local framework, considering soil as a receiving environment and ensuring pollution will not be transferred from one medium to another (water to soil). Country efforts should be targeted at quantitative risk assessments. This would allow a more optimal and prioritized management considering that agricultural reuse can cause a very real public health problem if the risk is not taken into account.

The risks of wastewater reuse in agriculture are extensive, ranging from changes to physicochemical and microbiological properties of soils to impacts on human health. In unfavorable economic conditions, the search for alternative irrigation sources irrigation, such as the reuse of raw or inadequately treated wastewater may result in avoidable risk factors. Thus, it is necessary to communicate the beneficial aspects of this practice, as well as the negative impacts and different low-cost strategies that contribute to the decision-making process and favor the adequate use of wastewater in agriculture.

The lack of quantitative evaluation of microbiological risk, referring to the concentration of helminths, is the missing piece that is required for the proper implementation of agricultural reuse. This deficiency has promoted the use of raw sewage water, triggered by the incipient development of norms and the standards of some countries that do not conform to global guidelines. In addition, the improvement of the detection technique of helminths should be the next milestone to eliminate subjectivity and to advance the safe reuse of residual water.

Acknowledgments: The authors thank the Vicerrectoría de Investigaciones of the Universidad del Valle and the resources of the COLCIENCIAS Scholarship Program No. 727-2015. This work received funding from the DGIS UNESCO-IHE Programmatic Cooperation 2016-2020 (DUPC), grant number 106471.

Author Contributions: María Fernanda Jaramillo: Realization of literature review, design of the article’s structure and its drafted. Inés Restrepo: Review of the paper's drafting.

Conflicts of Interest: The authors declare no conflict of interest. 


\section{References}

1. Brega Filho, D.; Mancuso, P.C. Reúso de Água; Universidade de São Paulo-Facultade de Saúde Pública: São Paulo, Brasil, 2003; p. 579.

2. Manga, J.; Logreira, N.; Serrait, J. Reuso de aguas residuales: Un recurso hídrico disponible. Ingeniería y Desarrollo 2001, 9, 12-21.

3. Jaramillo, M.F. Potencial de Reuso de Aguas Residuales Domesticas como Estrategia de Prevención y Control de la Contaminación en el Valle Geográfico del rio Cauca. Master's Thesis, Universidad del Valle, Cali, Colombia, 2014.

4. Angelakis, A.; Snyder, S. Wastewater treatment and reuse: Past, present, and future. Water 2015, 7, 4887-4895. [CrossRef]

5. Angelakis, A.; Gikas, P. Water reuse: Overview of current practices and trends in the world with emphasis in eu states. Water Util. 2014, 8, 67-78.

6. Tzanakakis, V.; Paranychianaki, N.; Angelakis, A. Soil as a wastewater treatment system: Historical development. Water Sci. Technol. Water Suppl. 2007, 7, 67-75. [CrossRef]

7. Cooper, P. Historical aspect of wastewater treatment. In Decentralised Sanitation Reuse: Concepts, System and Implementation; IWA Publishing: London, UK, 2001; pp. 11-38.

8. Drechsel, P.; Scott, A.; Sally, R.; Redwood, M.; Bachir, A. Wastewater Irrigation and Health: Assessing and Mitigating Risk in Low-Income Countries; International Water Management Institute, Ed.; Earthscan: London, UK, 2010.

9. Tzanakakis, V.; Koo-Oshima, S.; Haddad, M.; Apostolidis, N.; Angelakis, A. The history of land application and hydroponic systems for wastewater treatment and reuse. In Evolution of Sanitation and Wastewater Technologies through the Centuries; IWA Publishing: London, UK, 2014; p. 457.

10. Felizatto, M. Projeto integrado de tratamento avançado e reúso direto de águas residuárias. In Proceedings of the 21 Congresso Brasileiro de Engenharia Sanitária e Ambiental, João Pessoa, Brasil, 16-21 September 2001; pp. 1-17.

11. Seguí, A. Sistemas de Regeneración y Reutilización de Aguas Residuales. Metodología para el Análisis Técnico-Económico y Casos. Ph.D. Thesis, Universidad Politécnica de Cataluña Espana, Barcelona, Spain, 2004.

12. Barona, J.; Mestre, J. La Salud y el Estado: El Movimiento Sanitario Internacional y la Administración Española (1815-1945); Universitat de València: València, Spain, 2008.

13. Asano, T.; Burton, F.; Leverenz, H.; Tsuchihashi, R.; Tchobanoglous, G. Water Reuse: Issues, Technologies and Applications; McGraw Hill Professional: New York, NY, USA, 2007.

14. Asano, T.; Levine, A. Wastewater reclamation, recycling and reuse: Past, present, and future. Water Sci. Technol. 1996, 33, 1-14.

15. Jiménez, B.; Asano, T. Water Reuse: An International Survey of Current Practice, Issues and Needs; IWA Publishing: London, UK, 2008.

16. Carr, R. Who guidelines for safe wastewater use-more than just numbers. Irrig. Drain.-Chichester 2005, 54, 103-111. [CrossRef]

17. WHO. Health Guidelines for the Use of Wastewater in Agriculture and Aquaculture; WHO: Geneva, Switzerland, 1989.

18. Kamizoulis, G. Setting health based targets for water reuse (in agriculture). Desalination 2008, 218, $154-163$. [CrossRef]

19. Mara, D.; Sleigh, P.; Blumenthal, U.; Carr, R. Health risks in wastewater irrigation: Comparing estimates from quantitative microbial risk analyses and epidemiological studies. J. Water Health 2007, 5, 39-50. [CrossRef] [PubMed]

20. Mara, D.; Kramer, A. The 2006 who guidelines for wastewater and greywater use in agriculture: A practical interpretation. In Efficient Management of Wastewater; Springer: Berlin, Germany, 2008; pp. 1-17.

21. WHO. Guidelines for the Safe Use of Wastewater. Excreta and Greywater in Agriculture. Volume 2. Wastewater Use in Agriculture; WHO Press: Geneve, Switzerland, 2006.

22. Ayers, R.; Wescott, D. Water Quality for Agriuclture; FAO: Rome, Italy, 1985; p. 174.

23. FAO. Wastewater Treatment and Use in Agriculture. Avaliable online: http://www.fao.org/docrep/T0551E/ T0551E00.htm (accessed on 30 April 2017). 
24. Environmental Protection Agency. Guidelines for Water Reuse; U.S. Environmental Protection Agency: Washington, DC, USA, 2004.

25. Environmental Protection Agency; U.S. Agency for International Development. Guidelines for Water Reuse; U.S. Environmental Protection Agency: Washington, DC, USA, 2012.

26. Wintgens, T.; Bixio, D.; Thoeye, C.; Jeffrey, P.; Hochstrat, R.; Melin, T. Integrated Concepts for Reuse of Upgraded Wastewater; AQUAREC: Aachen, Germany, 2006.

27. Winpenny, J.; Heinz, I.; Koo-Oshima, S.; Salgot, M.; Collado, J.; Hérnandez, F.; Torricelli, R. Reutilización del Agua en Agricultura: Beneficios para Todos; FAO: Rome, Italy, 2013; Volome 124.

28. Bixio, D.; Wintgens, T. Water Reuse System Management Manual Aquarec; Office for Official Publications of the European Communities, European Commission: Brussels, Belgium, 2006.

29. Silva, J.; Torres, P.; Madera, C. Reuso de aguas residuales domésticas en agricultura. Una revisión. Agron. Colomb. 2008, 26, 347-359.

30. Becerra, C.; Lopes, A.; Vaz, I.; Silva, E.; Manaia, C.; Nunes, O. Wastewater reuse in irrigation: A microbiological perspective on implications in soil fertility and human and environmental health. Environ. Int. 2015, 75, 117-135. [CrossRef] [PubMed]

31. United Nations World Water Assessment Programme. The United Nations World Water Development Report 2017: Wastewater, The Untapped Resource; UNESCO: Paris, France, 2017.

32. Banco Mundial. Protección de la Calidad del Agua Subterránea. Guía Para Empresas de Agua, Autoridades Municipales y Agencias Ambientales; Banco Mundial: Washington, DC, USA, 2002.

33. Pimentel, D.; Pimentel, M. Food, Energy, and Society; Taylor \& Francis Group: Boca Raton, FL, USA, 2008.

34. Corcoran, E.; Nellemann, C.; Baker, E.; Bos, R.; Osborn, D.; Savelli, H. Sick Water? The Central Role of Wastewater Management in Sustainable Development: A Rapid Response Assessment; Earthprint: Arendal, Norway, 2010.

35. FAO. The State of Food Insecurity in the World 2015. Meeting the 2015 International Hunger Targets: Taking Stock of Uneven Progress; FAO: Rome, Italy, 2015.

36. Cruz, R. Medición del agua de riego. Tecnicaña 2009, 34, 27-33.

37. Moscoso, J. Aspectos Técnicos de la Agricultura con Aguas Residuales. Availabe online: http://bvsper.paho. org/bvsacd/scan/019502.pdf (accessed on 25 September 2017).

38. Barreto, A.; Do Nascimento, J.; Medeiros, E.; Nóbrega, J.; Bezerra, J. Changes in chemical attributes of a fluvent cultivated with castor bean and irrigated with wastewater. Revista Brasileira de Engenharia Agrícola e Ambiental 2013, 17, 480-486. [CrossRef]

39. Henze, M.; Comeau, Y. Wastewater characterization. In Biological Wastewater Treatment: Principles, Modelling and Design; IWA Publishing: London, UK, 2008; pp. 33-52.

40. Liu, Y.; Haynes, R. Origin, nature, and treatment of effluents from dairy and meat processing factories and the effects of their irrigation on the quality of agricultural soils. Crit. Rev. Environ. Sci. Technol. 2011, 41, 1531-1599. [CrossRef]

41. Jimenez, B. Wastewater reuse to increase soil productivity. Water Sci. Technol. 1995, 32, 173-180.

42. Lal, K.; Yadav, R.; Kaur, R.; Bundela, D.; Khan, M.I.; Chaudhary, M.; Meena, R.; Dar, S.; Singh, G. Productivity, essential oil yield, and heavy metal accumulation in lemon grass (cymbopogon flexuosus) under varied wastewater-groundwater irrigation regimes. Ind. Crops Prod. 2013, 45, 270-278. [CrossRef]

43. Matheyarasu, R.; Seshadri, B.; Bolan, N.S.; Naidu, R. Abattoir wastewater irrigation increases the availability of nutrients and influences on plant growth and development. Water Air Soil Pollut. 2016, 8, 227-253. [CrossRef] [PubMed]

44. Oliveira, S.; Von Sperling, M. Reliability analysis of wastewater treatment plants. Water Res. 2008, 42, 1182-1194. [CrossRef] [PubMed]

45. Adrover, M.; Farrús, E.; Moyà, G.; Vadell, J. Chemical properties and biological activity in soils of mallorca following twenty years of treated wastewater irrigation. Environ. Manag. 2012, 95, S188-S192. [CrossRef] [PubMed]

46. Fatta-Kassinos, D.; Kalavrouziotis, I.; Koukoulakis, P.; Vasquez, M. The risks associated with wastewater reuse and xenobiotics in the agroecological environment. Sci. Total Environ. 2011, 409, 3555-3563. [CrossRef] [PubMed]

47. Toze, S. Reuse of effluent water. Benefits and risks. Agric. Water Manag. 2006, 80, 147-159. [CrossRef] 
48. Umaña, E. El reuso de aguas residuales para riego en un cultivo de maíz (Zea mays L.) una alternativa ambiental y productiva. La Calera 2011, 7, 22-26.

49. Candela, L.; Fabregat, S.; Josa, A.; Suriol, J.; Vigués, N.; Mas, J. Assessment of soil and groundwater impacts by treated urban wastewater reuse. A case study: Application in a golf course (girona, spain). Sci. Total Environ. 2007, 374, 26-35. [CrossRef] [PubMed]

50. Moscoso, J.; Egocheaga, L. Sistemas integrados de tratamiento y uso de aguas residuales en américa latina: Realidad y potencial. In Congreso Iberoamericano de Ingeniería Sanitaria y Ambiental; AIDIS: Lima, Peru, 2002.

51. Zambrano, D. Minimización y Prevención Como Estrategia Para el Control de la Contaminación por Aguas Residuales Municipales en la Zona de Expansión de Cali. Master's Thesis, Universidad del Valle, Cali, Colombia, 2012.

52. Hernández, F.; Molinos, M.; Sala, R. Economic valuation of environmental benefits from wastewater treatment processes: An empirical approach for Spain. Sci. Total. Environ. 2010, 408, 953-957. [CrossRef] [PubMed]

53. Gerba, C.; Rose, J. International guidelines for water recycling: Microbiological considerations. Water Sci. Technol. 2003, 3, 311-316.

54. Jiménez, B.; Mara, D.; Carr, R.; Brissaud, F. Wastewater treament for pathogen removal and nutrient conservation: Suitable systems for use in developing countries. In Wastewater Irrigation and Health: Assessing and Mitigating Risk in Low-Income Countries; Earthscan: London, UK, 2010.

55. Craun, G.; Regli, S.; Clark, R.; Bull, R.; Doull, J.; Grabow, W.; Marsh, G.; Okun, D.; Sobsey, M.; Symons, J. Balancing chemical and microbial risks of drinking water disinfection. Part II managing the risks. Aqua 1994, 43, 207-218.

56. Guerra de Macedo, C. Ponderación de los riesgos de origen microbiano y químico en la desinfección del agua potable: La perspectiva panamericana. Bol Sanit Panam 1993, 115, 451-454.

57. Romero, J. Acuiquímica; Escuela colombiana de ingeniería: Bogotá, Colombia, 1996.

58. Von Sperling, M. Princípios do Tratamento Biológico de Águas Residuárias: Principios Básicos so Tratamento de Esgoto; UFMG universitarios: Minas Gerais, Brasil, 1996; p. 243.

59. Jiménez, B.; Rose, J. Urban Water Security: Managing Risks; UNESCO Publishing: New York, NY, USA, 2009.

60. Evans, B.; Mara, D. Sanitation and Water Supply in Low-Income Countries; Ventus Publishing: Leedes, UK, 2011.

61. Jiménez, C. Contaminantes orgánicos emergentes en el ambiente: Productos farmacéuticos. Lasallista Investig. 2011, 8, 143-153.

62. Heberer, T. Tracking persistent pharmaceutical residues from municipal sewage to drinking water. J. Hydrol. 2002, 266, 175-189. [CrossRef]

63. Kasprzyk-Hordern, B.; Dinsdale, R.; Guwy, A. The removal of pharmaceuticals, personal care products, endocrine disruptors and illicit drugs during wastewater treatment and its impact on the quality of receiving waters. Water Res. 2009, 43, 363-380. [CrossRef] [PubMed]

64. Jackson, J.; Sutton, R. Sources of endocrine-disrupting chemicals in urban wastewater, Oakland, CA. Sci. Total Environ. 2008, 405, 153-160. [CrossRef] [PubMed]

65. Postigo, C. Estudio de las Drogas y Sus Metabolitos Como Contaminantes Ambientales en Agua y Aire y Como Indicadores de Consumo Poblacional. Ph.D. Thesis, Universidad de Barcelona, Barcelona, Espana, 2011.

66. Grassi, M.; Rizzo, L.; Farina, A. Endocrine disruptors compounds, pharmaceuticals and personal care products in urban wastewater: Implications for agricultural reuse and their removal by adsorption process. Environ. Sci. Pollut. Res. 2013, 20, 3616-3628. [CrossRef] [PubMed]

67. Alcalde, L. Evaluación y Gestión del Riesgo Asociado a la Reutilización de Aguas Residuales. Ph.D. Thesis, Universidad de Barcelona, Barcelona, Espana, 2012.

68. Fent, K.; Weston, A.; Caminada, D. Ecotoxicology of human pharmaceuticals. Aquat. Toxicol. 2006, 76, 122-159. [CrossRef] [PubMed]

69. Hutchinson, T.; Ankley, G.; Segner, H.; Tyler, C. Screening and testing for endocrine disruption in fish-biomarkers as "signposts", not "traffic lights", in risk assessment. Environ. Health Perspect. 2006, 114, 106. [CrossRef] [PubMed]

70. Ternes, T.; Bonerz, M.; Schmidt, T. Determination of neutral pharmaceuticals in wastewater and rivers by liquid chromatography-electrospray tandem mass spectrometry. J. Chromatogr. A 2001, 938, 175-185. [CrossRef] 
71. Baquero, F.; Martínez, J.; Cantón, R. Antibiotics and antibiotic resistance in water environments. Curr. Opin. Biotechnol. 2008, 19, 260-265. [CrossRef] [PubMed]

72. Bloom, P. Soil ph and ph buffering. In Handbook of Soil Science: Properties and Processes; CRC Press: Boca Raton, FL, USA, 2000; pp. B333-B352.

73. Sparks, D. Environmental Soil Chemistry; Elservier Science: San Diego, CA, USA, 2003.

74. Brady, N.; Weil, R. The Nature and Properties of Soils; Perason: Washington, DC, USA, 2002.

75. Fierer, N.; Jackson, R.B. The diversity and biogeography of soil bacterial communities. Proc. Natl. Acad. Sci. USA 2006, 103, 626-631. [CrossRef] [PubMed]

76. Lauber, C.L.; Hamady, M.; Knight, R.; Fierer, N. Pyrosequencing-based assessment of soil ph as a predictor of soil bacterial community structure at the continental scale. Appl. Environ. Microbiol. 2009, 75, 5111-5120. [CrossRef] [PubMed]

77. Rattan, R.; Datta, S.; Chhonkar, P.; Suribabu, K.; Singh, A. Long-term impact of irrigation with sewage effluents on heavy metal content in soils, crops and groundwater-A case study. Agric. Ecosyst. Environ. 2005, 109, 310-322. [CrossRef]

78. Rousk, J.; Bååth, E.; Brookes, P.; Lauber, C.; Lozupone, C.; Caporaso, G.; Knight, R.; Fierer, N. Soil bacterial and fungal communities across a ph gradient in an arable soil. ISME J. 2010, 4, 1340-1351. [CrossRef] [PubMed]

79. Julca, A.; Meneses, L.; Blas, R.; Bello, S. La materia orgánica, importancia y experiencia de su uso en la agricultura. Idesia 2006, 24, 49-61.

80. Andrade, M.; Marcet, P.; Reyzábal, M.; Montero, M. Contenido, evolución de nutrientes y productividad en un suelo tratado con lodos residuales urbanos. Edafología 2000, 7, 21-29.

81. Macías, F. Recuperación de suelos degradados, reutilización de residuos y secuestro de carbono. Una alternativa integral de mejora de la calidad ambiental. Recursos Rurais 2004, 1, 49-56.

82. Baldock, J.; Nelson, P. Soil organic matter. In Handbook of Soil Sciences; CRC Press: Boca Raton, FL, USA, 2000; pp. B25-B84.

83. Powlson, D.; Smith, P.; Smith, J.U. Evaluation of Soil Organic Matter Models: Using Existing Long-Term Datasets; Springer Science \& Business Media: Harpenden, UK, 2013; Volume 38.

84. Thompson, L.; Troeh, F. Los Suelos y su Fertilidad; Reverté Edition; McGraw-Hill: Barcelona, Espana, 1988.

85. Sun, H.; Terhonen, E.; Koskinen, K.; Paulin, L.; Kasanen, R.; Asiegbu, F.O. Bacterial diversity and community structure along different peat soils in boreal forest. Appl. Soil Ecol. 2014, 74, 37-45. [CrossRef]

86. Ranjard, L.; Richaume, A. Quantitative and qualitative microscale distribution of bacteria in soil. Res. Microbiol. 2001, 152, 707-716. [CrossRef]

87. White, P.; Greenwood, D. Properties and management of cationic elements for crop growth. In Soil Conditions and Plant Growth; Wiley-Blackwell: Ames, IA, USA, 2013; pp. 160-194.

88. Levy, G.; Lordian, A.; Goldstein, D.; Borisover, M. Soil structural indices' dependence on irrigation water quality and their association with chromophoric components in dissolved organic matter. Eur. J. Soil Sci. 2014, 65, 197-205. [CrossRef]

89. Murcia, M.; Calderón, O.; Díaz, J. Impacto de aguas grises en propiedades físicas del suelo. Tecno Lógicas 2014, 17, 57-65. [CrossRef]

90. Pérez, F.; Madera, C.; Echeverri, A.; Urrutia, N. Wastewater reuse: Impact on the chemical and macronutritional attributes of an inceptisol irrigated with treated domestic wastewater. Ing. Compet. 2015, 17, 19-28.

91. DeForest, J.; Zak, D.; Pregitzer, K.; Burton, A. Atmospheric nitrate deposition, microbial community composition, and enzyme activity in northern hardwood forests. Soil Sci. Soc. Am. 2004, 68, 132-138. [CrossRef]

92. Habteselassie, M.; Xu, L.; Norton, J. Ammonia-oxidizer communities in an agricultural soil treated with contrasting nitrogen sources. Front. Microbiol. 2013. [CrossRef] [PubMed]

93. Haynes, R.; Naidu, R. Influence of lime, fertilizer and manure applications on soil organic matter content and soil physical conditions: A review. Nutr. Cycl. Agroecosyst. 1998, 51, 123-137. [CrossRef]

94. Knobeloch, L.; Salna, B.; Hogan, A.; Postle, J.; Anderson, H. Blue babies and nitrate-contaminated well water. Environ. Health Perspect. 2000, 108, 675. [CrossRef] [PubMed]

95. Kuramae, E.; Gamper, H.; van Veen, J.; Kowalchuk, G. Soil and plant factors driving the community of soil-borne microorganisms across chronosequences of secondary succession of chalk grasslands with a neutral ph. FEMS Microbiol. Ecol. 2011, 77, 285-294. [CrossRef] [PubMed] 
96. Ramírez, K.; Craine, J.; Fierer, N. Consistent effects of nitrogen amendments on soil microbial communities and processes across biomes. Glob. Chang. Biol. 2012, 18, 1918-1927. [CrossRef]

97. $\mathrm{Wu}, \mathrm{R}$. Eutrophication, water borne pathogens and xenobiotic compounds: Environmental risks and challenges. Mar. Pollut. Bull. 1999, 39, 11-22. [CrossRef]

98. Zörb, C.; Senbayram, M.; Peiter, E. Potassium in agriculture-Status and perspectives. J. Plant Physiol. 2014, 171, 656-669. [CrossRef] [PubMed]

99. Chee-Sanford, J.; Mackie, R.; Koike, S.; Krapac, I.; Lin, Y.-F.; Yannarell, A.; Maxwell, S.; Aminov, R. Fate and transport of antibiotic residues and antibiotic resistance genes following land application of manure waste. J. Environ. Q. 2009, 38, 1086-1108. [CrossRef] [PubMed]

100. De Oliveira Marinho, L.; Coraucci Filho, B.; Roston, D.; Stefanutti, R.; Tonetti, A. Evaluation of the productivity of irrigated eucalyptus grandis with reclaimed wastewater and effects on soil. Water Air Soil Pollut. 2014, 225, 1-7.

101. Ke, C.; Li, Z.; Liang, Y.; Tao, W.; Du, M. Impacts of chloride de-icing salt on bulk soils, fungi, and bacterial populations surrounding the plant rhizosphere. Appl. Soil Ecol. 2013, 72, 69-78. [CrossRef]

102. Rietz, D.; Haynes, R. Effects of irrigation-induced salinity and sodicity on soil microbial activity. Soil Biol. Biochem. 2003, 35, 845-854. [CrossRef]

103. Sarig, S.; Roberson, E.; Firestone, M. Microbial activity-soil structure: Response to saline water irrigation. Soil Biol Biochem. 1993, 25, 693-697. [CrossRef]

104. Wong, V.; Dalal, R.; Greene, R. Salinity and sodicity effects on respiration and microbial biomass of soil. Biol. Fertil. Soils 2008, 44, 943-953. [CrossRef]

105. Baccaro, K.; Degorgue, M.; Lucca, M.; Picone, L.; Zamuner, E.; Andreoli, Y. Calidad del agua para consumo humano y riego en muestras del cinturón hortícola de mar del plata. Rev. Investig. Agropecu. 2006, 35, 95-110.

106. Barrios, I. Calidad de Aguas Naturales y Residuales en el Sistema Hidrográfico Valle del Mezquital, Hidalgo México. Master's Thesis, Institución de Enseñanza e Investigación en Ciencias Agrícolas, Texcoco, Mexico, 2014.

107. FAO. Advances in the Assessment and Monitoring of Salinization and Status of Biosaline Agriculture. Reports of Expert Consultation Held in Dubai, United Arab Emirates; FAO: Rome, Italy, 2007.

108. Echeverri, A. Reúso Para Riego del Rfluente de la Ptar-C: Evaluación del Potencial Impacto en las Propiedades Físicas del Suelo y la Productividad de la Variedad de Caña de Azúcar CC 85-92. Master's Thesis, Universidad del Valle, Cali, Colombia, 2011.

109. Halliwell, D.; Barlow, K.; Nash, D. A review of the effects of wastewater sodium on soil physical properties and their implications for irrigation systems. Aust. J. Soil Res. 2001, 39, 1259-1267. [CrossRef]

110. Lado, M.; Ben-Hur, M. Treated domestic sewage irrigation effects on soil hydraulic properties in arid and semiarid zones: A review. Soil Till. Res. 2009, 106, 152-163. [CrossRef]

111. Travis, M.J.; Wiel-Shafran, A.; Weisbrod, N.; Adar, E.; Gross, A. Greywater reuse for irrigation: Effect on soil properties. Sci. Total Environ. 2010, 408, 2501-2508. [CrossRef] [PubMed]

112. Chowdhury, N.; Marschner, P.; Burns, R. Soil microbial activity and community composition: Impact of changes in matric and osmotic potential. Soil Biol. Biochem. 2011, 43, 1229-1236. [CrossRef]

113. Yuan, B.-C.; Li, Z.-Z.; Liu, H.; Gao, M.; Zhang, Y.-Y. Microbial biomass and activity in salt affected soils under arid conditions. Appl. Soil Ecol. 2007, 35, 319-328. [CrossRef]

114. Bååth, E. Effects of heavy metals in soil on microbial processes and populations (a review). Water Air Soil Pollut. 1989, 47, 335-379. [CrossRef]

115. Correa, P.; Lin, L.; Just, C.; Hu, D.; Hornbuckle, K.; Schnoor, J.; Van Aken, B. The effects of individual pcb congeners on the soil bacterial community structure and the abundance of biphenyl dioxygenase genes. Environ. Int. 2010, 36, 901-906. [CrossRef] [PubMed]

116. DeRito, C.; Pumphrey, G.; Madsen, E. Use of field-based stable isotope probing to identify adapted populations and track carbon flow through a phenol-degrading soil microbial community. Appl. Environ. Microbiol. 2005, 71, 7858-7865. [CrossRef] [PubMed]

117. Ding, C.; He, J. Effect of antibiotics in the environment on microbial populations. Appl. Microbiol. Biotechnol. 2010, 87, 925-941. [CrossRef] [PubMed]

118. Müller, A.; Westergaard, K.; Christensen, S.; Sorensen, S.J. The diversity and function of soil microbial communities exposed to different disturbances. Microb. Ecol. 2002, 44, 49-58. [CrossRef] [PubMed]

119. Parks, J.; Edwards, M. Boron in the environment. Crit. Rev. Environ. Sci. Technol. 2007, 35, 81-114. [CrossRef] 
120. Rooklidge, S.J. Environmental antimicrobial contamination from terraccumulation and diffuse pollution pathways. Sci. Total Environ. 2004, 325, 1-13. [CrossRef] [PubMed]

121. Sánchez, M.; González, J.; Martínez, M.; Pozo, C.; Rodelas, B. Influence of linear alkylbenzene sulfonate (las) on the structure of alphaproteobacteria, actinobacteria, and acidobacteria communities in a soil microcosm. Environ. Sci. Pollut. Res. 2010, 17, 779-790. [CrossRef] [PubMed]

122. Swartjes, F. Dealing with Contaminated Sites: From Theory towards Practical Application; Springer Science \& Business Media: Bilthoven, The Netherlands, 2011.

123. Baker, C.; Wright, M.; Stepanauskas, R.; McArthur, J. Co-selection of antibiotic and metal resistance. Trends Microbiol. 2006, 14, 176-182. [CrossRef] [PubMed]

124. Brookes, P. The use of microbial parameters in monitoring soil pollution by heavy metals. Biol. Fertil. Soils 1995, 19, 269-279. [CrossRef]

125. Ellis, R.J.; Neish, B.; Trett, M.W.; Best, J.G.; Weightman, A.J.; Morgan, P.; Fry, J.C. Comparison of microbial and meiofaunal community analyses for determining impact of heavy metal contamination. J. Microbiol. Methods. 2001, 45, 171-185. [CrossRef]

126. Guadarrama-Brito, M.; Fernández, A. Impacto del uso de agua residual en la agricultura. CIBA Revis. Iberoam. Cienc. Biol. Agropecu. 2015, 4, 22-44.

127. Kong, W.-D.; Zhu, Y.-G.; Fu, B.-J.; Marschner, P.; He, J.-Z. The veterinary antibiotic oxytetracycline and $\mathrm{Cu}$ influence functional diversity of the soil microbial community. Environm. Pollut. 2006, 143, 129-137. [CrossRef] [PubMed]

128. López, S.; Gallegos, M.; Flores, L.; Rojas, M. Mecanismos de fitorremediación de suelos contaminados con moléculas orgánicas xenobióticas. Contam. Ambient. 2010, 21, 91-100.

129. Soltan, E.-S.M. Isolation and characterization of antibiotic and heavy metal-resistant pseudomonas aeruginosa from different polluted waters in sohag district, egypt. J. Microbiol. Biotechnol. 2001, 11, 50-55.

130. Zúñiga, F. Introducción al Estudio de la Contaminación del Suelo por Metales Pesados; Ediciones de la Universidad Autónoma de Yucatán: Mérida, Mexico, 1999; Volume 1.

131. Avisar, D.; Lester, Y.; Ronen, D. Sulfamethoxazole contamination of a deep phreatic aquifer. Sci. Total Environ. 2009, 407, 4278-4282. [CrossRef] [PubMed]

132. Biel, M. Estimación de la Movilidad del Ibuprofeno en Suelos Agrícolas. Master's Thesis, Universidad de Alcalá, Alcalá de Henares, Espana, 2012.

133. Gozlan, I.; Rotstein, A.; Avisar, D. Amoxicillin-degradation products formed under controlled environmental conditions: Identification and determination in the aquatic environment. Chemosphere 2013, 91, 985-992. [CrossRef] [PubMed]

134. Hirsch, R.; Ternes, T.; Haberer, K.; Kratz, K.-L. Occurrence of antibiotics in the aquatic environment. Sci. Total Environ. 1999, 225, 109-118. [CrossRef]

135. López, A.; Becerra, D.; Llerena, J.; Cox, L.; Albarrán, A.; Peña, D. Movilidad de bentazona en suelos dedicados a cultivo de arroz aeróbico con siembra directa y tradicional inundado. In V Congreso Ibérico de Ciencia do Solo; Universidade dos Açores: Angra do Heroismo, Brasil, 2012; p. 88.

136. Li, S.-X.; Wang, Z.-H.; Stewart, B. Responses of crop plants to ammonium and nitrate n. Adv. Agron 2013, 118, 205-397.

137. Oke, O. Nitrite toxicity to plants. Nature 1966, 212, 528. [CrossRef]

138. Anjana, S.U.; Iqbal, M. Nitrate accumulation in plants, factors affecting the process, and human health implications. A review. Agron. Sustain. Dev. 2007, 27, 45-57. [CrossRef]

139. Mujeriego, R. La reutilización, la regulación y la desalación del agua. Ing. Territ. 2005, 72, 16-25.

140. McArthur, J.V.; Tuckfield, R.C. Spatial patterns in antibiotic resistance among stream bacteria: Effects of industrial pollution. Appl. Environ. Microbiol. 2000, 66, 3722-3726. [CrossRef] [PubMed]

141. Chefetz, B.; Mualem, T.; Ben-Ari, J. Sorption and mobility of pharmaceutical compounds in soil irrigated with reclaimed wastewater. Chemosphere 2008, 73, 1335-1343. [CrossRef] [PubMed]

142. Chen, F.; Ying, G.-G.; Kong, L.-X.; Wang, L.; Zhao, J.-L.; Zhou, L.-J.; Zhang, L.-J. Distribution and accumulation of endocrine-disrupting chemicals and pharmaceuticals in wastewater irrigated soils in Hebei, China. Environ. Pollut. 2011, 159, 1490-1498. [CrossRef] [PubMed]

143. Dalkmann, P.; Broszat, M.; Siebe, C.; Willaschek, E.; Sakinc, T.; Huebner, J.; Amelung, W.; Grohmann, E.; Siemens, J. Accumulation of pharmaceuticals, enterococcus, and resistance genes in soils irrigated with wastewater for zero to 100 years in central mexico. PLoS ONE 2012, 7, 1-11. [CrossRef] 
144. Gibson, R.; Durán-Álvarez, J.; León, K.; Chávez, A.; Jiménez, B. Accumulation and leaching potential of some pharmaceuticals and potential endocrine disruptors in soils irrigated with wastewater in the tula valley, mexico. Chemosphere 2010, 81, 1437-1445. [CrossRef] [PubMed]

145. González, V. Efectos Sinérgicos en el Análisis Ecotoxicológico del Ibuprofeno. Aproximación Cuantitativa del Riesgo Ambiental. Ph.D. Thesis, Universidad de Alcalá, Alcalá de Henares, Espana, 2013.

146. Moscoso, J. Manual de Buenas Prácticas Para el Uso Seguro y Productivo de las Aguas Residuales Domésticas; Autoridad Nacional del Agua: Lima, Peru, 2016; p. 226.

147. Monteiro, T.; Alcayhuaman, R. Capítulo 3. Plan de seguridad de saneamiento: Fundamentos y perpescivas de implementación. In Uso Seguro del Agua Para el Reúso; Unesco y Programa Hidrológico Internacional: São Paulo, Brasil, 2016; pp. 43-61.

148. Jiménez, B. Capítulo 7. El reúso del agua y la seguridad alimentaria. In Uso Seguro del Agua Para el Reúso; Unesco y Programa Hidrológico Internacional: São Paulo, Brasil, 2016; pp. 43-61.

149. González, M.I.; Chiroles, S. Safe use and microbiological risks of wastewater for agriculture. Revis. Cubana Salud Públ. 2011, 37, 61-73.

150. Hamilton, A.J.; Stagnitti, F.; Kumarage, S.C.; Premier, R.R. Rira: A tool for conducting health risk assessments for irrigation of edible crops with recycled water. Comput. Electron. Agric. 2007, 57, 80-87. [CrossRef]

151. Mok, H.-F.; Barker, S.F.; Hamilton, A.J. A probabilistic quantitative microbial risk assessment model of norovirus disease burden from wastewater irrigation of vegetables in shepparton, australia. Water Res. 2014, 54, 347-362. [CrossRef] [PubMed]

152. Barker, S.F.; O’Toole, J.; Sinclair, M.I.; Leder, K.; Malawaraarachchi, M.; Hamilton, A.J. A probabilistic model of norovirus disease burden associated with greywater irrigation of home-produced lettuce in melbourne, australia. Water Res. 2013, 47, 1421-1432. [CrossRef] [PubMed]

153. Liu, C.; Grillner, L.; Jonsson, K.; Linde, A.; Shen, K.; Lindell, A.T.; Wirgart, B.Z.; Johansen, K. Identification of viral agents associated with diarrhea in young children during a winter season in Beijing, China. J. Clin. Virol. 2006, 35, 69-72. [CrossRef] [PubMed]

154. Asano, T.; Leong, L.; Rigby, M.; Sakaji, R. Evaluation of the california wastewater reclamation criteria using enteric virus monitoring data. Water Sci. Technol. 1992, 26, 1513-1524.

155. Petterson, S.R.; Ashbolt, N.J.; Sharma, A. Microbial risks from wastewater irrigation of salad crops: A screening-level risk assessment. Water Environ. Res. 2001, 73, 667-672. [CrossRef] [PubMed]

156. Mok, H.-F.; Hamilton, A.J. Exposure factors for wastewater irrigated asian vegetables and a probabilistic rotavirus disease burden model for their consumption. Risk Anal. 2014, 34, 602-613. [CrossRef] [PubMed]

157. Ackerson, N.O.; Awuah, E. Microbial risk assessment of urban agricultural farming: A case study on kwame nkrumah university of science and technology campus, kumasi, ghana. Int. Eng. Technol. 2012, 2, 356-363.

158. Jiménez, B.; Maya, C.; Barrios, J.A.; Navarro, I. Helminths and their role in environmental engineering. In Human Helminthiasis; InTech: Rijeka, Croatia, 2017. 